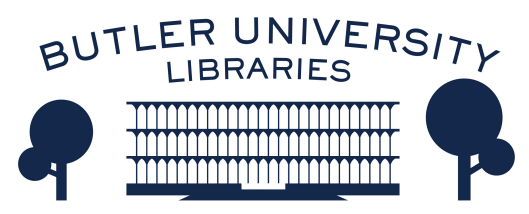

Journal of Hindu-Christian Studies

Volume 23

Article 10

January 2010

\title{
A World Filled With Grace: Conceptualizing the Divine in Hindu Devotionalism and Karl Rahner
}

Ankur Barua

Follow this and additional works at: https://digitalcommons.butler.edu/jhcs

Part of the Religion Commons

\section{Recommended Citation}

Barua, Ankur (2010) "A World Filled With Grace: Conceptualizing the Divine in Hindu Devotionalism and Karl Rahner," Journal of Hindu-Christian Studies: Vol. 23, Article 10.

Available at: https://doi.org/10.7825/2164-6279.1462

The Journal of Hindu-Christian Studies is a publication of the Society for Hindu-Christian Studies. The digital version is made available by Digital Commons @ Butler University. For questions about the Journal or the Society, please contact cbauman@butler.edu. For more information about Digital Commons @ Butler University, please contact digitalscholarship@butler.edu. 


\title{
A World Filled With Grace: Conceptualizing the Divine in Hindu Devotionalism and Karl Rahner
}

\author{
Ankur Barua \\ University of Cambridge
}

IN recent decades, a substantial body of scholarly work in the field of Hindu-Christian studies has been produced, which has not only done much to dispel earlier stereotypes of Hindu life-worlds as steeped in 'pantheism', 'worldnegation' and the like, but also urged Christian thinkers to reflect on their own foundational beliefs through Hindu motifs. A relatively unexplored theme remains that of whether, and in what ways, the divine reality can be conceptualized as 'gracious' in Hindu devotionalism, especially given that the Christian doctrine of 'grace' is related to a constellation of other notions such as creation out of nothing, justification and so on, which have no clear analogues in the former. In this article, I seek to trace certain parallels to the Christian understanding of 'grace' in some figures of South Indian Śrī-Vaiṣnavism through a dialogue with the thought of Karl Rahner, and show how they attempt, in their specific theological contexts, to affirm both the divine freedom and the divine accessibility to all human beings. Karl Rahner, one of the most influential Roman Catholic theologians of the last century, emphasized the gratuitousness of grace while denying that grace is offered only to a limited few chosen by the divine will. In the universe of Srī-Vaișnavism, structured by a distinctive understanding of the divine-human relation within an Upanișadic framework, theologians struggled with a similar question of whether divine grace, which is uncaused, can be said to be freely offered to all human beings.

We shall begin with an outline of the Christian understanding of prevenient or antecedent grace, and then move on to consider certain parallels to this conceptualization of divine agency in the Hindu religious traditions. The Christian diagnosis of the human predicament is that the correct relationship with God is now ruptured because of the fault of human beings, and they cannot restore it through their unaided efforts. The consciousness of this fault is expressed through the language of ' $\sin$ ', and it is significant that the Greek word that Paul uses in these contexts, hamartia, means the failure to hit the mark or the goal. The mark here is the 'supreme Thou' in front of whom the 'subjects of sin' have the fearful consciousness that they face the divine wrath for their lack of truthful relationship with God. ${ }^{1}$ Nevertheless, God also steadfastly seeks the reconciliation of the world, and by turning human beings away from their sinful immersion into themselves graciously draws them to Godself through the atoning death of Christ. In.writing about how Christ has brought about a decisive transformation in the lives of those who have become incorporated into his Body, Paul therefore invokes the metaphor of a transfer from one owner (servility to sin) to another (the

Ankur Barua completed his Ph.D. from the Faculty of Divinity, University of Cambridge, in 2005. He is currently a Teape Research Fellow in Hindu-Christian Studies at the same faculty. His research interests are Hindu-Christian dialogue and comparative philosophy of religion. His publications include The Divine Body in History: A Comparative Study of Time and Embodiment in the Theologies of St Augustine and Ramanuja (Peter Lang, 2009) and articles in Oxford Journal of Hindu Studies, Journal of the Indian Council of Philosophical Research, Harvard Theological Review, and International Journal of Hindu Studies. 
new life under the grace of Christ). ${ }^{2}$ Given this close interconnection between these key Christian doctrines, it is not surprising that many Christian theologians have commented on the absence of the notion or consciousness of 'sin', and consequently. that of 'grace' as the forgiveness of sin by the 'holy' God, in the Hindu traditions. ${ }^{3}$ We may take these observations as a warning against a too hasty application of the Christian understanding of 'sin' and 'grace' to Hindu religious contexts. Scholars in comparative philosophy have rightly alerted us to the dangers of plucking out concepts from diverse contexts and squeezing them into a Procrustean bed by chopping off their distinctive edges. However, this attention to the specificity of origin need not hinder us in trying to sketch certain resemblances to the conceptions of 'sin' and 'grace' in some Hindu theistic currents, especially when we keep in mind the notion of ' $\sin$ ' in terms of the failure to hit the mark, in this case the divine reality. In the following, we shall outline some of the similarities to the Christian conceptions of 'sin' and 'grace' in the three figures of Mānikkavācakar, the ninth-century bhakti poet of Tamil Śaivism, Nammālvār, the author of the Tiruvāymoli, and Rāmānuja, one of the most important theologians of Śrī-Vaiṣnavism.

$$
\text { * * * }
$$

In the Tiruvācakam, Mānikkavācakar sings praises of the Lord Siva who takes the initiative not only in breaking his bondage to samsāra but also in graciously possessing him and melting his heart. It is only because of Siva's grace (arul) that the 'base' Mānikkavācakar is able to understand the Lord and enter into communion with his transcendent master who is beyond speech and mind. In Glenn E. Yocum's reading of the Tiruvācakam the unconstrained grace of the 'playful' Siva releases a creature (paśu) like Mānikkavācakar from the cycle of rebirths and fills him with madness (pittam) which transcends the limitations of worldly wisdom (catur). ${ }^{5}$ This dialectic of the Lord Siva's sovereignty and intimate presence also appears in some of the other canonical texts of the Śaiva Siddhānta which revolve around the conception of God as the unique supreme Person (Śiva) who is both the transcendent Lord and the immanent indweller of all beings. In the verses of the Saivite poets such as Campantar (first half of the seventh century $\mathrm{CE}$ ) and his contemporary Appar, one comes across expressions of their sense of self-abasement and their deep awareness of their vileness in the presence of Siva before whom they are unworthy to sing his praises. Evoking the metaphor of conjugal union they speak of Siva as the bridegroom and the soul (paśu) as his bride, and yet declare that the devotional love with which they seek communion with him is itself generated and brought to fruition by the grace of Siva. ${ }^{6}$ The dual emphasis on the spontaneous and unconditioned nature of divine grace, on the one hand, and the individual's consciousness of separation from the divine, on the other, emerges also in Nammālvār's Tiruvāymoli which constitutes a major part of the 'Tamil Vedas'. In a detailed study of the Tiruvāymoli R. David Kaylor notes that there are seemingly contradictory passages regarding the question of whether grace, understood as the Lord's favourable action or attitude to humans, is totally spontaneous or responsive to human deeds. Kaylor concludes that though certain passages which speak of the results of ritualistic deeds or the worship of the Lord at temples or self-surrender to the Lord seem to indicate that the Lord responds to individuals in keeping with their character or deeds, these passages must be read within a context which emphasizes the priority of 'prevenient' grace. ${ }^{7}$ Thus Nammālvār speaks of himself as unworthy to be the Lord's slave, and states that he is devoid of any quality that might have prompted the Lord to look graciously towards him. For Nammālvār the transcendent Lord who cannot be known except. through His self-manifestation is also graciously accessible through his many incarnations, icons in temples and presence as the inner controller in all humans, and this dialectic of divine sovereignty and immediate accessibility plays an important role in the theology of Rāmānuja. The root meaning of ' $\sin$ ' as the lack of a veridical relationship with the divine underlies his claim that because the embodied self has since beginningless times moved away from the Lord 
and does not have the correct knowledge that it is an 'accessory' of the Lord, it is therefore immersed in 'sinfulness' ( $p a \overline{p a})$. Therefore, the self's burden of pappa may be regarded, in this specific sense, as 'sinful' in a manner that has some resonances with the Christian understanding of 'sin' as the attempt to emancipate oneself from God and thereby become lord unto oneself. Thus, Rāmānuja speaks of those born with a 'demoniac' nature who get further entangled in the bonds of samsāra and who have qualities such as deceitfulness (dambba), pride (darpa), arrogance (abhimāna) and ignorance. ${ }^{8}$ This contextualised notion of 'sin' ( $p \bar{a} p a)$ allows us to speak, in a carefully qualified manner, of the Lord as 'graciously' (prasāda) assisting the embodied self on its journey towards liberation (mokssa). Commenting on the text Katha Upanișad I, 2, 23, Rāmannuja explains that it declares that it is not possible for the finite self to attain the Lord, whose Body (sarira) it is, through the mere hearing of scripture, reflection on it and meditation on it, for only they who have been chosen by Him shall obtain this supreme end, which is Himself. ${ }^{9}$ In other words, the embodied self does not attain the Lord through some sort of 'Pelagian' efforts of the will, for Rāmānuja insists that the self derives its agency not from itself but from the Lord who is the inner Controller of all its actions. ${ }^{10}$

Now the fact that the Lord is the supreme cause behind everything in the world raises the question of whether the finite self can indeed perform actions which will be the object of moral appraisal. ${ }^{11}$ To this problem, Rāmānuja replies as follows: the Lord has equipped human beings with the instruments necessary for performing action (such as the organs of speech, the power of thought and willing) and remains within them as their Support and inner Controller while with the help of these capacities they either perform or desist from action. When the finite self chooses to perform a certain act, the Lord aids it by consenting to its fulfilment, and without such permission (anumati) no action is possible. In the final analysis, then, we must affirm both that it is the Lord who is the ultimate cause behind every action and that nevertheless the finite self remains a moral agent capable of receiving either praise or blame for its actions. In this manner, Rāmānuja is able to affirm both that the embodied selves can attain release from the stream of samisāra only by surrendering themselves to the Lord (bhagavatprapatti); ${ }^{12}$ and that by seeking refuge (prapad-) in the Lord they shall perform all actions with the knowledge that it is the Lord who is the supreme Agent behind them. ${ }^{13}$

In short, while there are no clear analogues in the Hindu traditions of the Christian understanding of 'justification' through Christ's atoning death, one can note in them certain parallels to the Christian conception of grace and of human beings who, having fallen away from the divine reality, require divine assistance to bridge this gap. Nevertheless, we should not overlook the crucial differences between the Hindu traditions and Christianity in their respective understandings of grace, and these divergences are rooted in their different conceptualisation of the gap between God and the world. For most Christian theologians from Augustine to Anselm to Aquinas and beyond who accept the doctrine of creation out of nothingness, there is an ontological rupture between God and human beings, so that grace is usually regarded as a 'gratuitous' element, freely added by God to what the world has in its "natural' constitution. ${ }^{14}$ Consequently, most of the Christian traditions emphasise the 'prevenience' and the unmerited quality of divine grace: human beings do not have any 'natural' claims over God's grace which is a freely offered gift for their salvation. On the other hand, many Hindu religious traditions accept a doctrine of causality called satkāryavāda according to which there is an ontological continuum between the 'cause', namely Brahman, and the 'effect', namely the phenomenal world. For Rāmānuja the Lord is the original cause and ultimate source out of which the various differentiated beings in the world emerge as an effect, which implies that when the Lord assists human beings to overcome their worldly bondage this 'gracious' help does not arrive from across an ontological fissure. ${ }^{15}$ Consequently, the Lord's grace may be viewed less as an 'intrusion' or a 'supplement' to what human beings 'naturally' do not possess 
and more as a 'reinforcement' of what they essentially are, that is, rooted in the innermost reality of the Lord as parts of His Body. Nevertheless, while Rāmānuja does not strike the strong note of divine help as 'unmerited', he is emphatic that without the Lord human beings cannot overcome their sinfulness, namely, their ignorance, in the form of karma, of their existential grounding in the Lord. Therefore Emil Brunner, the Swiss Reformed theologian, is not quite correct when he writes regarding the 'grace' religion of bhakti: 'But the "grace" which is here meant is not the forgiveness of sin; thus it is not the grace of the holy God, in whose presence $\sin$ is guilt and who takes guilt seriously...,16 Now while the AugustinianAnselmian notions of 'guilt', associated with some 'models' of the Atonement, may not be easily translatable into Vedantic terms, the Lord's gracious aid does not arrive in spite of 'sin'. Rāmānuja writes that though the Lord seeks to increase the happiness of the embodied selves to the outmost degree, $\mathrm{He}$ also rejects the sins that they have accumulated over countless numbers of aeons. ${ }^{17}$ Therefore, the way back to the Lord through the perils of samsāra must not be understood as a process of self-striving unaided by Him, for the devotees' performance of Vedic sacrificial rituals, meditation on the Lord and all such Lord-directed actions are possible only because it is, in fact, the Lord who has set them on the path towards Himself. ${ }^{18}$

In the preceding sections, we have highlighted the conceptualisations of divine grace in some of the Hindu religious traditions and Christianity, and in particular their commonalities and their divergences. Regarding the former, we have noted the themes of a ruptured relationship with the divine Lord who is utterly transcendent and yet intimately present, of the sense of condemnation because of moral unworthiness and of divine assistance that reaches out to human beings in their conditions of worldly imperfections. The differences, as we have pointed out, revolve around two divergent ways of understanding the divine-human gap: in many Hindu traditions the human self is essentially united with the divine reality but unaware of this deep communion because it is immersed in worldly limitations, while most Christian theologians hold that the individual is not ontologically divine before the infusion of grace, which is supernature offered gratuitously to human nature. ${ }^{19}$ In the following two sections, however, we shall add some further nuances to this picture by showing how even these differences are not as sharp as they might seem to be at first glance. On the one hand, we shall show that the questions of whether grace is 'unmerited' and whether it is offered universally to all, which have generated so much dispute in the Christian centuries, are not unknown in the Hindu worlds. On the other hand, by investigating some aspects of the theology of Karl Rahner, we shall point out how a major Christian thinker, while retaining the naturesupernature distinction, rejected some of its implications and developed a vision of the world filled with grace which has strong parallels with a Śrī-Vaisnava understanding of the world as intrinsically 'engraced' by the divine reality.

A few centuries after Rāmānuja's death the religious community was split into two groups, the Vadagalais and the Tenkalais, over the question of the precise nature of the relationship between the disciplined effort on the part of the devotee who responds to the Lord, and the 'grace' (prasāda) of the Lord who chooses the devotee as His 'beloved'. ${ }^{20}$ These Vaiṣnavite groups are well-known in the popular literature through the similes of the 'cat' and the 'monkey', but we should be wary of regarding them as clearly demarcated standpoints, for as Srilata Raman has pointed out, the differences between the two parties were formalised only in the late nineteenth century. She writes that the eighteen differences which are traditionally supposed to divide the two groups can in fact be narrowed down to two. The first revolves around the conception of the Lord as a parent full of graciousness (prasāda), love (vātsalya) and mercy (dayā): the Vadagalais believed that the Lord's gracious approach to the devotees was not unconditional but was responsive to their moral worthiness, whereas the Tenkalais claimed that the Lord's graciousness was unfathomable and freely given with no 
consideration of prior actions. The second was over the status of the act of self-surrender (prapatti): the Vadagalais accepted it as one of the many paths towards the Lord, while the Tenkalais insisted that the resignation of one's efforts and taking refugee in the Lord was the sole means of attaining the Lord. $^{21}$ The Vadagalais claimed that liberation is effected by both the Lord's election of the devotee and the devotee's positive response through devotion, and this relationship between the Lord and the devotee is to be understood on the analogy of the co-operation between a baby monkey and its mother, the baby holding on to its mother as she takes her baby along with her. The Tenkalais rather emphasized that the devotees must profess their inability to go through the various practices such as sacrifices and meditation on the Lord which form a part of the devotional life, and surrender themselves to the Lord who alone can carry them to Himself. The analogy here is that of a baby kitten which is, without any effort on its part, carried away by its mother; similarly, what is accentuated in the human case is the unworthiness of the devotees before the Lord to whom they must resort as the refuge and implore for help in attaining the highest goal, the Lord Himself. ${ }^{22}$

As a matter of fact, both groups were at one on the question of the Lord's 'uncaused grace' (nirhetukakrpā): the Lord's merciful approach to the world is unconditional (niraupādhika) and innate (sahaja) in that when $\mathrm{He}$ raises bound selves out of the cycle of rebirth this action is not caused by anything external to His nature. Where they disagreed with each other was over the thorny question of whether when $\mathrm{He}$ did make Himself mercifully accessible to a specific bound self at a specific time, one can continue to speak of an 'uncaused grace' of the Lord or whether this is partially conditioned by the self's previous karma. The reputed founder of the Tenikalai sect Manavālamāmuni argued that the Lord's gracious karma-erasing glance in itself was efficacious in removing sins from an unworthy individual such as Nammālvār who had not performed any religious austerity nor practised any yogas. Vedānta Deśika developed the Vadagalai position that the Lord, who as the supreme governor of the kārmic law, metes out rewards and punishments to individual selves, also mercifully helps these selves to move towards Himself by producing devotional love in them: 'The sovereignty of one without mercy is oppressive. The compassion of one who is not sovereign is of no help to others and brings pain to himself' ${ }^{23}$ Vedānta Deśika argues that if the Lord liberates individuals in an 'arbitrary' manner with no regard for their previous karma He should have, to be truly merciful and not cruel or partial to those whom He does not choose, drawn all of them towards Himself. Instead, the Lord has laid down certain pretexts (vyajas), such as the act of taking refuge in the Lord or performing the discipline of bhakti yoga, and when the individual takes up one of these means towards liberation (mokșa), the Lord, with His disfavour towards them pacified, brings them towards Himself by destroying their ignorance. Therefore it is the ripening of the self's karma at a specific time, with the Lord continuously upholding the kārmic order, that produces in it the desire for mokssa, and Nammālvār's liberation too took place through the fruition of his past karma. ${ }^{24}$

In other words, given the conception of the Lord as the upholder of the kanrmic order, the following dilemma may be presented: either the impersonal law of karma operates independently of the Lord; in which case the Lord is not absolutely supreme, or the Lord cannot suspend the kārmic effects for individuals, in which case we cannot meaningfully speak of special divine 'intervention'. If the law of karma is inviolable, then there is no arbitrariness about the world in which every individual receives the just deserts for her prior actions, but if the Lord cannot intervene and loosen the connection between past actions and present conditions according to His will, the Lord cannot intervene in human affairs. A possible response is to view such 'intervention' not in terms of the Lord as the remover of the kârmic debts of a specific individual but as the ever-present empowerer of human agency who by administering the law of karma enables individuals to move closer to Himself. ${ }^{25}$ This response is, in effect, the Vadagalai resolution of the dilemma: Vedānta Deśika emphasized that there need not be any conflict between the Lord's favour and the 
karmic order, for though the law of karma is in one sense the juridical principle that people invariably 'reap what they have sown', it is ultimately an expression of the Lord's grace since it is through its operation that He draws human beings towards Him over a series of births. However, the self is not an autonomous entity effecting its own liberation, for it is the Lord who as the universal agent (sarvakarta) makes possible the fruition of good karma, and when this results in the performance of good action, the Lord responds by prompting the self to move towards bhakti or the act of surrender (prapatti).

Now the Tenkalai concern seems to be that under this conception of the Lord's relation to the law of karma, the Lord becomes its 'mere' administrator and cannot possibly bring about the liberation of unmeritorious individuals such as Nammālvãr. They argued that in order to safeguard the Lord's supremacy over the world one must emphasize that $\mathrm{He}$ can raise any self without regard to its previous karma towards Himself; and, indeed, the Lord's ability to rescue even an unworthy person, such as Nammālvār, who could not 'boast' of his kārmic merits since he had none, demonstrates His mercy. However, if the Vadagalai understanding of "intervention' threatens to push the Lord into the background, the Tenkalais had to face the charge of arbitrariness, known as sarvamuktiprasanga: if the individual's response indeed plays no role in the Lord's compassionate approach to the world, the Lord should have liberated all selves and not just a specific few. In response, Manavālamāmuni points to the 'hiddenness' of the divine wisdom and develops the analogy of a king who takes one woman to be his queen out of many. The king's will being beyond questioning, his subjects do not dispute his preference, and a fortiori when the infinitely more sovereign Lord desires to grant release to one of his 'accessories' (śeșa) we may not seek to discover the reason for this choice. ${ }^{26}$

$$
* \quad * \quad *
$$

In other words, if the Lord's gracious assistance is 'intrinsic' to the kārmic cycle, He is not sovereign over it and would seem to be under some sort of obligation to the embodied selves to give them their kārmic dues, but if this divine aid is 'extrinsic', and is offered to only a few individuals, $\mathrm{He}$ would be subject to the charge of being partial and cruel. ${ }^{27}$ In the Catholic theology of Karl Rahner, this dialectic between divine freedom and divine accessibility appears in his attempt to steer a middle course between the notion of 'extrinsicism' in neoscholasticism and the 'intrinsicism' of the nouvelle theologie. ${ }^{28}$ Rahner writes that neoscholastic writers in the sixteenth and seventeenth centuries proposed an 'extrinsecism' which makes a sharp distinction between a state of 'pure nature' (natura pura) within which human beings are ordinarily circumscribed and 'supernatural grace' which by intruding into the former 'disturbs' it in an extrinsic manner. The neo-scholastics were therefore led to argue that God must first elevate the 'natural' individual through created grace, orientating her through an 'entitative modification' towards God, and then indwelling her as the Holy Spirit (pneuma hagion). In short, they made 'uncreated grace' (donum increatum) a function of 'created grace', but this understanding of the relation between the two is, according to Rahner, a reversal of that of Paul for whom it was created grace that was a manifestation of the indwelling presence of the Holy Spirit. ${ }^{29}$ Because nature is regarded as a self-sufficient realm that is not 'always already' orientated towards God, grace could only appear to be an external superstructure imposed on the former, with the implication that until an individual experiences grace through the verbal revelation preached by the Church, she remains locked into a state of pure nature. ${ }^{30}$ Secondly, the neo-scholastic conception that the ordination of the individual to the supernatural end remains purely exterior until she is 'seized' by grace mistakenly presupposes that 'the possibility of experiencing grace and the possibility of experiencing grace as grace are ... the same thing. ${ }^{31}$ This is based, argues Rahner, on the false assumption that we can neatly delimit the spheres of 'nature' and 'grace' so that we can thereby extract or quarantine those experiences which we attribute to supernatural grace from the totality of our experiences in our personal conscious life. He affirms that because all 
human beings are already encompassed by the divine salvific will, no 'neat horizontal' can be drawn isolating from each other the realms of 'supernatural grace' and a 'chemically pure nature'. He therefore questions whether our supposedly 'natural' existential experiences, such as our deep yearnings and the tragedy of death, would be just what they are now if we 'were not [already] called to eternal communion with the God of grace, were not exposed to the permanent dynamism of grace and were not to feel its loss a mortal wound on account of being continuously ordained to it in [our] most inmost depths? ${ }^{32}$

Nevertheless, Rahner seeks, at the same time, to steer a path away from the 'intrinsicism' of some French Catholic theologians who implied that God was somehow 'obligated' to satisfy the intrinsic or natural desire (desiderium naturale) for God. The central question for Rahner therefore becomes whether one can insist that grace is truly gratuitous while emphasizing that human nature is already incorporated within a supernatural order which provides human ex-sistence with its dynamism towards God. Now Rahner argues that human beings, in their concrete historical experiences, are orientated towards God and have the 'potency' for grace, but this existential capacity is itself created in us by God's free selfcommunication. Therefore, our desire for God is not 'in virtue of nature as such' but is an everabiding disposition of receptivity created in us by divine grace as the 'supernatural existential' which always remains at the very core of our existence. ${ }^{33}$ Consequently, the individual who receives God's unmerited 'saving grace' realizes, in the light of revelation, that her existential for God's love, her deep longing for God, is not an inherent dynamism of her 'nature' but is itself unowed to her as a free gift. Through the transcendence or the excessus of the spirit towards the infinity of God which is inspired by the supernatural existential, human beings are drawn towards saving and justifying grace which they may accept or refuse. Therefore, though the stirrings of grace within the human heart are not of themselves sufficient for justification unless human beings freely accept the divine self-communication with faith and love, certain acts which flow from their existence elevated by grace, such as morally good decisions, can be regarded as "supernaturally salutary. ${ }^{34}$ Consequently, when the message of faith reaches the individual she is made consciously aware of a gracious reality of which she did not have conceptual knowledge but within which she was already encompassed.

In short, our comparative analysis of the debates within Śrī-Vaiṣnavism over the Lord's approach to the world and Karl Rahner's conception of the 'supernatural existential' has pointed to some parallels in the understanding of the divine reality as 'gracious'. In their own distinctive contexts, Śri-Vaiṣnava theologians and Karl Rahner are trying to negotiate the tension between affirming that the divine reality is sovereign over the world and is yet most intimately present in it. They diverge at crucial points, given their respective commitments to the doctrines of satkāryavāda and creation ex nihilo, but both emphasize, using their specific theological vocabulary, that the divine reality is 'graciously' accessible to human beings as they seek, with divine aid, to find their way to their transcendent home. J. B. Carman, who shows how Rāmānuja tries to emphasize both the accessibility of the Lord to the devotee and His perfection and supremacy, puts the point in this way: 'We can feel in Christian faith the same tension that Rāmānuja senses in his apprehension of the Lord revealed to him in the Vedas and through the Vedānta and the ŚriVaiṣnava tradition. That tension is the inner dynamic of the supreme lordship and utter availability within the same Divine nature and the same Divine person. That is why, although Christians stand outside Ramanuja's tradition, they are able to grasp and appreciate so much of his thought. ${ }^{35}$

This mutual emphasis has at least two implications for Hindu-Christian dialogue on the question of 'grace', especially in the context of the oft-repeated statement that the Hindu religious traditions do not conceptualize the deity as 'gracious'. To begin with the position of Śñ-Vaișnavism on this matter, we have noted that some of its strands strike a strong 'Augustinian' note of the gratuitousness of grace when they emphasize that the Lord's assistance 
to the embodied selves is freely offered without any consideration of their karmic records. However, the key difference between Christian orthodoxy and Vedāntic theology at this point is that the distinction between 'nature' and 'supernature' is more readily drawn in the former than in the latter. While the distinction between 'nature' in terms of the contingent self which does not know that its true destiny is to serve the Lord and 'supernature' in terms of the Lord's assistance it receives as it moves towards liberation is not entirely alien to Rāmānuja's world-view, it cannot be clearly drawn either, for all embodied selves are already included, sustained and 'engraced' by the Lord as parts of His divine Body. The Lord 'graciously' supports all human beings as their innermost element (antaryāmin), for $\mathrm{He}$ is under no external or internal constraints when He manifests the world as His play (lila a), and assists them on their journeys through samisanra and towards Himself. Across the boundaries of theological worldviews, Rahner speaks of the 'supernatural existential' which indicates, firstly, the indwelling of the Holy Spirit as a constitutive element or 'ingredient' (existential) of human self-transcendence, 'and, secondly, that this divine self-offering is absolutely unmerited and is prior to the freedom, consciousness and experiences of human beings. ${ }^{36}$ Consequently, in opposition to the Augustinian-Calvinist position that some individuals will not be encompassed by God's favour, Rahner argues that human beings are continuously influenced by the grace of God, noting that ' $[\mathrm{t}]$ heology has too long been bedeviled by the unavowed supposition that grace would no longer be grace if it were too generously distributed by God'..$^{37}$ In short, while all human beings are not necessarily justified by grace, especially before they have heard and responded to the Christian message, they are included within the ambit of the divine salvific will. ${ }^{38}$ Rahner's view that the ordination of nature to God is not a mere external decree of God but constitutes the innermost and active human dynamism towards grace therefore helps us to re-examine the claim that the notion of 'grace' is absent in the Hindu religious streams, on the grounds that in Christian doctrine grace is supernature that is distinct from human nature and is given unconditionally. ${ }^{39}$

\section{Notes}

1 Paul Ricoeur, The Symbolism of Evil. Translated from the French by Emerson Buchanan (London: Beacon Press, 1967), p. 69.

${ }^{2}$ J.A. Ziesler, Pauline Christianity (Oxford: Oxford University Press, 1983), p. 86.

${ }^{3}$ S. Kulandran, Grace in Christianity and Hinduism (London: Lutterworth Press, 1964), pp. 244-45.

4 Rudolf Otto, India's Religion of Grace and Christianity Compared (London: SCM, 1930).

5 Glenn E. Yocum, "Mānikkavācakar's Image of Siva", History of Religions 16 (1976):20-41.

${ }^{6}$ Mariasusai Dhavamony, Love of God According to Śaiva Siddhānta: A Study in the Mysticism and Theology of Śaivism (Oxford: Clarendon Press, 1971), pp. 354-360.

${ }^{7}$ R. David Kaylor, "The Concept of Grace in the Hymns of Nammālvār", Journal of the American Academy of Religion 44 (1976):649-660.

${ }^{8}$ Gìtā-Bhāṣya GB 16, 1-16, 5.

9 Śri-Bhāsya, SB I, 1, 1. George Thibaut, The Vedānta Sütras: With the Commentary by Rāmānuja (Delhi: Motilal Banarsidas, 1971), pp. 15-16.

${ }^{10}$ SB II, 3, 40. J.B. Carman, The Theology of Rămänuja: An Essay in Interreligious Understanding (New Haven and London: Yale University Press, 1974).

${ }^{11}$ SB II, 3, 40 (Thibaut, p. 557).

${ }_{12}$ Vedārthasamgraha VS 78.

13 GB 9, 27.

${ }^{14} \mathrm{~N}$. Joseph Torchia, Creatio ex nihilo and the theology of St. Augustine (New York: Peter Lang, 1999).

15 Rāmannuja explains that the effect is "not substantially different from the cause, but is, in fact, the cause which has passed into a different state. SB I, 4, 23 (Thibaut, p. 398).'

${ }_{16}$ Emil Brunner, Revelation and Reason (London: SCM, 1947), p. 271.

${ }^{17} \mathrm{SB}$ II, 2,3 .

18 Eric J. Lott, "The Conceptual Dimensions of Bhakti in the Rāmānuja Tradition", Scottish Journal of Religious Studies 2 (1981):97-114.

${ }_{19}^{19}$ Mariasusai Dhavamony, Love of God, p. 378.

${ }^{20}$ Robert C. Lester, "Rāmānuja and Śrī-Vaișnavism: The Concept of Prapatti or Śaranāgati", History of Religions 5 (1966):266-82.

${ }^{21}$ Srilata Raman, Self-Surrender (Prapatti) to God in Srā-Vaiṣnavism: Tamil Cats and Sanskrit Monkeys (London and New York: Routledge, 2007).

22 P.N. Srinivasachari, The Philosophy of Visișțadvaita (Madras, 1946), pp. 534-40. 
48 Ankur Barua

23 Patricia Y. Mumme, "Grace and Karma in Nammālvār's Salvation", Journal of the American Oriental Society 107 (1987):257-66, here p. 259.

${ }^{24}$ Patricia Y. Mumme, "Grace and Karma," pp. 25766, here p. 265.

${ }^{25}$ Bruce R. Reichenbach, "Karma, Causation and Divine Intervention", Philosophy East and West 39 (1989):135-49, here pp. 145-48.

${ }^{26}$ Patricia Y. Mumme, "Grace and Karma," pp. 257 66, here pp. 261-62.

${ }^{27}$ Francis X. Clooney, "Evil, Divine Omnipotence and Human Freedom: Vedänta's Theology of Karma", Journal of Religion 69 (1989):530-48.

${ }^{28}$ The term 'nouvelle theologie' was applied to a mid-twentieth century school of thought which included French and German Roman Catholic theologians such as Henri de Lubac, Teilhard de Chardin and Hans Urs von Balthasar.

${ }^{29}$ Karl Rahner, "Some Implications of the Scholastic Concept of Uncreated Grace" in Theological Investigations Volume 1: God, Christ, Mary and Grace. Translated by Cornelius Ernst (London: Darton, Longman \& Todd, 1961), pp. 319-346, here p. 322.

30 Karl Rahner, "Concerning the Relationship between Nature and Grace" in Theological Investigations Volume 1: God, Christ, Mary and Grace. Translated by Cornelius Ernst (London: Darton; Longman \& Todd, 1961), pp. 297-317, here pp. 299-303.

Karl Rahner, "Concerning the Relationship between Nature and Grace", pp. 297-317, here p. 300.

32 Karl Rahner, "Concerning the Relationship between Nature and Grace", pp. 297-317, here p. 301.

${ }^{33}$ Karl Rahner, "Concerning the Relationship between Nature and Grace", pp. 297-317, here p. 304.

${ }^{34}$ Karl Rahner, "Nature and Grace" in Theological Investigations Volume IV. Translated by Kevin Smyth (London: Darton, Longman and Todd, 1966), pp.165-188, here p. 180.

${ }^{35}$ J.B. Carman, The Theology of Rāmānuja, p. 271.

${ }^{36}$ Carmichael C. Peters, A Gadamerian Reading of Karl Rahner's Theology of Grace and Freedom (Lanham: Catholic Scholars Press, 2000), pp. 33435.

${ }^{37}$ Karl Rahner, "Nature and Grace", pp.165-88, here p. 180.

${ }^{38}$ Ann Carr, The Theological Method of Karl Rahner (Missoula: Scholars Press, 1977), p. 195.

${ }^{39}$ Mariasusai Dhavamony, Love of God, p. 378. 